\title{
Playing it Queer: Popular Music, Identity and Queer World-making
}

\author{
Jodie Taylor \\ Bern, Switzerland: Peter Lang, 2012 \\ ISBN 978-3-0343-0553-2 (PB)
}

\author{
Julia Downes \\ Lakehead University, Ontario, Canada \\ julia.downes@lakeheadu.ca
}

As an observer I was excited about the development and publication of Playing it Queer. I felt an affinity with Jodie Taylor from my position as a participant-researcher of contemporary queer feminist music cultures in the UK. I have found her previous discussions of queerness and age in music subcultures and ethical responsibilities illuminating and useful (Taylor 2010, 2011). The publication of this monograph, drawing on Taylor's ethnographic research of queer music scenes in Australia, UK, USA and Germany is an important development in popular music studies and queer cultural studies. The book boldly aims to look at "how queers use music to express gender and sexual differences, to empower and transform themselves, form queer social alliances and mobilise social protest" (Taylor 2012: 3). Taylor's affiliation with Andy Bennett is evident in her aim to critique and test out the 'scene' thesis in relation to translocal queer music cultures. Written with a popular music audience in mind, who may be unfamiliar with contemporary gender and queer theory, Chapter 1 offers an accessible overview of the key definitions, debates, theories and social movement histories. Chapter 2 develops an astute critique of subcultural studies and discussion of how music can be used as a resource to articulate identity and worlds. Whilst Chapter 3 traces the history of camp and considers the political usefulness of musical camp in queer music performance. The book is also aimed towards audiences who are familiar with queer theory but have not fully considered the role of music within queer studies. A particular strength of Taylor's scholarship is in her ability to situate her own personal experience of queerness and subcultural music participation as a femme bisexualqueer goth and uses her position as a 'critical insider' (Taylor 2012: 6) to guide methodological and ethical decisions in doing research within worlds that can also be a place of personal belonging.

Taylor focuses her analysis on the 'extra-musical' or 'para-musical' qualities of music in queer identity work and queer world making. In this way music is theorised as the excess of the sound object and attention is focused on how music affords identities and social groups. This strategy is reminiscent of previous popular music scholarship on gender and queerness in popular music (Halberstam 2005, 2007; Whiteley 1997; Whiteley \& Rycenga 2006). However the focus on the 'extra-musical' could also be 
considered a side-step from a more contentious set of tensions between queer feminisms and popular music studies. Namely the convention that music can exist as a 'pure' or 'authentic' form - the music itself - that escapes the social muddying that scholars with an interest in class, race, ethnicity, genders and sexualities engage in. Those of us engaged in musical research of this kind commonly experience the argument that we are not actually talking about music at all and such projects are considered peripheral to popular musicology and relegated to sociology or cultural studies. Discussions of the production of knowledge about music have long established problems with this idea of the musical object as biased towards a white, western, masculine and heteronormative perspective of what music is (Maus 1993; Stock 1998; Cusick 1999). Therefore despite a recent increase in opportunities to consider both popular music and queer lives within academic spheres - many problematic frameworks (and possible publisher requirements) remain that ultimately limit the radical projects to adding in an element (be it gender or sexuality) onto existing frameworks. The frameworks themselves have not been undone.

For instance, although Taylor critiques subcultural theory and argues that the complexities of queer lives are obscured by a theorisation of stylistic, public and spectacular acts, nonetheless the case studies selected focus on public and spectacular performances by the drag king and bio queen collective The Twang Gang (Chapter 4), queer punk band Anal Traffic (Chapter 5) and riot grrrl band Bertha Control (Chapter 6). Each chapter is predominated by contextual and historical overviews including a survey of what popular music studies has already done. This limits the discussion of how music was deliberately deployed in the fabric of everyday lives, non-oppositional queer resistance and in moments of conflict and crisis in queer activisms. I craved these case study chapters to consist of rich ethnographies in which I could immerse, feel and hear the chaos and conflict of queer musical worlds radically questioning what music is, ridiculing the cultural baggage that protects music making for the 'professionals' and 'talented few' and constructing values outside a mainstream or oppositional dynamic. In contrast Chapters 4-6 seemed well behaved in focusing on interpreting public displays, the body and song choices from the perspectives of Taylor's observations and interviews with the performers. Music is left relatively unscathed. Binaries from popular music studies re-emerge, for instance the rock/pop binary that argues that rock is historically male dominated and masculine, an argument that obscures and further marginalises the role of women in producing, shaping and creating rock (Fast 2008). Chapters 5 and 6 see a gender dichotomy emerging between queercore and riot grrrl. Where the 'Bertha vibe' ethic to performing music confirms essentialist notions of womanhood as nurturing, healing and non-hierarchical, Anal Traffic seem to confirm dominant ideas of masculine sexuality as active. Disruptive controversies, for instance the criticism that Anal Traffic faced for their song about the age of consent, blamed the audience for 'misconstruing' the bands intended message. Diverse perspectives of wider music participants crucial for meaning-making - audience members, fanzine writers, photographers, organisers, sound technicians were absent from these chapters.

Thankfully these voices do emerge in Chapter 7, and here we get to the richness of Taylor's ethnographic work in Brisbane and Berlin and Taylor's arguments about queer musicality are more nuanced here. The queer ethic is described as a disidentification from a homo-myth: "queer has come to signify a particular stylistic approach to the way some gender and social minority subjects structure scenic counter-publics, which may include but necessarily exceed mainstream gay style" (Taylor 2012: 208-9). Controversies are touched on in the discussion on utopias where excluded subjects are seen to confront the "tyranny of the homonormative" (Taylor 2012: 213). Although Taylor acknowledges the slipperiness of queer and the homo-myth, queer is restricted to oppositional identity politics. I wonder if popular music studies frameworks and the 'extra-musical' focus have limited the radical potential of Playing it Queer. For instance 
it has been argued that "values of queer culture are not oppositional to mainstream values - they come from a liberatory set of commitments driven by a different conception of life's possibilities and priorities" (Jeppesen 2010: 475). Accordingly a "successful radical politics cannot rely on oppositionality alone" (Jeppesen 2010: 475) but the creation of different values, spaces, publics that promote participatory engagements. Therefore a radical project on queerness would do much to start from queer values and lives rather than distinguish queer worlds from their relationship to the mainstream.

\section{References}

Cusick, S. G. (1999) Gender, Musicology, and Feminism. In, Nicholas Cook and Mark Everist (eds.) Rethinking Music. Oxford \& New York: Oxford University Press, pp. 471-498

Fast, S. (2008) Girls, Rock Your Boys: The Continuing (non)History of Women in Rock. In Annette Kreutziger-Herr and Katrin Losleben (eds.) History/Herstory: Andere Musikgeschichten. Koln \& Weimar: Bohlau, pp. 154-176

Halberstam, J. -

(2005) In a Queer Time and Place: Transgender Bodies, Subcultural Lives. New York: NYU Press

(2007) Keeping Time with Lesbians on Ecstasy. Women and Music: A Journal of Gender and Culture. 11: 51-58.

Jeppesen, S. (2010) Queer Anarchist Autonomous Zones and Publics: Direct Action Vomiting Against Homonormative Consumerism. Sexualities. 13(4): 463-478

Maus, F. E. (1993) Masculine Discourse in Music Theory. Perspectives of New Music, $31(2): 264-293$

Stock, J. P. J. (1998) New Musicologies, Old Musicologies: Ethnomusicology and the Study of Western Music. Current Musicology, 62: 40-68

Taylor, J. -

(2010) Queer Temporalities and the Significance of 'Music Scene' Participation in the Social Identities of Middle-aged Queers. Sociology. 44(5): 893-907

(2011) The intimate insider: negotiating the ethics of friendship when doing insider research, Qualitative Research. 11(1): 3-22

Whiteley, S. (ed.) (1997) Sexing the Groove: Popular Music and Gender. London \& New York: Routledge

Whiteley, S. and Rycenga, J. (eds.) (2006) Queering the Popular Pitch. London \& New York: Routledge 